DOI: https://doi.org/10.47405/mjssh.v5i11.546

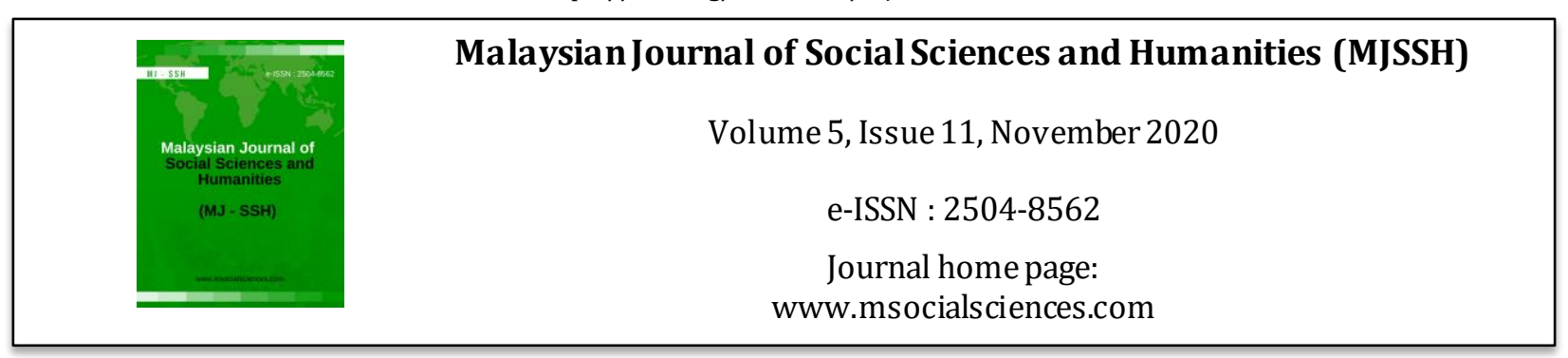

\title{
Pengetahuan Teknologi Maklumat dan Komunikasi Guru Matematik Sekolah Rendah
}

\author{
Janet Lau Siew Chee', Roslinda Binti Rosli ${ }^{1}$ \\ 1Fakulti Pendidikan, Universiti Kebangsaan Malaysia (UKM) \\ Correspondence: Janet Lau Siew Chee (p99524@siswa.ukm.edu.my)
}

\begin{abstract}
Abstrak
Pembelajaran maya yang merupakan proses pembelajaran dan pemudahcaraan (PdPc) berasaskan Internet adalah bidang yang turut berkembang di Malaysia dalam era Teknologi Maklumat dan Komunikasi (TMK) ini. Walau bagaimanapun, tugas mengintegrasikan TMK ke dalam pengajaran bilik darjah terutamanya subjek Matematik dengan cara yang bermakna dan canggih masih mencabar. Walaupun bilik darjah mempunyai akses kepada teknologi, terdapat beberapa keadaan yang mempengaruhi pelaksanaan teknologi di bilik darjah seperti infrastruktur yang tidak lengkap, teknologi yang tidak mencukupi, pembangunan profesional yang berkesan, keberkesanan kendiri guru dan persepsi guru. Guru juga jarang mengintegrasikan teknologi dalam PdPc Matematik disebabkan kecekapan mereka adalah terhad kepada kemahiran asas TMK. Maka, kajian ini bertujuan untuk meninjau pengetahuan TMK guru Matematik sekolah rendah Malaysia dan pengetahuan penggunaan TMK dalam PdPc Matematik. Seramai enam puluh lima orang guru Matematik dari tiga buah Sekolah Jenis Kebangsaan Cina yang terlibat dalam kajian ini. Kajian ini merupakan kajian tinjauan yang menggunakan soal selidik untuk mengumpul data. Analisis statistik deskriptif digunakan untuk menjawab soalan persoalan. Data-data yang dikumpulkan akan diproses dengan menggunakan perisian statistik SPSS versi 25. Analisis data menunjukkan pengetahuan TMK guru Matematik sekolah rendah Malaysia dan pengetahuan penggunaan TMK dalam PdPc Matematik adalah pada tahap yang sederhana sahaja. Berdasarkan hasil kajian, adalah dicadangkan pengurusan sekolah boleh mengatur latihan dalam perkhidmatan secara berkala dalam kursus pengembangan profesional untuk guru. Dengan kursus yang dijalankan, diharapkan dapat meningkatkan kecekapan guru dan mengurangkan kegelisahan mereka dalam menggunakan TMK dalam PdPc.
\end{abstract}

Kata kunci: teknologi maklumat dan komunikasi, proses pembelajaran dan pemudahcaraan, pengetahuan guru

\section{Primary School Mathematics Teachers' Knowledge of Information and Communication Technology}

\begin{abstract}
Virtual learning which is an Internet-based learning and facilitation process is a field that is also developing in Malaysia in this ICT era. However, the task of integrating ICT into classroom teaching especially Mathematics subjects in a meaningful and sophisticated way is still challenging. Although the classroom has access to technology, there are several conditions that affect the implementation of technology in the classroom such as incomplete infrastructure, inadequate technology, effective professional development, teacher self-efficacy and teacher perception. Teachers also rarely integrate
\end{abstract}


technology in PdPc Mathematics because their competencies are limited to basic ICT skills. Therefore, this study aims to review the ICT knowledge of Malaysian primary school Mathematics teachers and the knowledge of the use of ICT in Mathematics teaching. A total of sixty-five Mathematics teachers from three Chinese Primary Schools were involved in this study. This study is a survey study that uses questionnaires to collect data. Descriptive statistical analysis was used to answer the questionnaire. The data collected will be processed using SPSS version 25 statistical software. Data analysis shows that the knowledge of ICT of Malaysian primary school Mathematics teachers and knowledge of the use of ICT in Mathematics teaching is at a moderate level only. Based on the results of the study, it is suggested that school management can arrange in-service training regularly in professional development courses for teachers. With the courses conducted, it is hoped to increase the efficiency of teachers and reduce their anxiety in using ICT in teaching.

Keywords: ict, mathematics teaching, teacher knowledge

\section{Pengenalan}

Sejak Internet diperkenalkan dalam sistem pendidikan di Malaysia, banyak perubahan telah berlaku (Zaira, Zolkefli \& Saidon 2016). Ia telah mengubah corak hidup komuniti serta masyarakat di seluruh negara dan jelas memperlihatkan penggunaannya dalam bidang pendidikan. Pembelajaran maya yang merupakan proses PdPc berasaskan Internet adalah bidang yang turut berkembang dalam era TMK ini. Inisiatif sekolah pintar Malaysia (smart school) mula dilancarkan pada tahun 1999. Kementerian Pelajaran Malaysia (1997) mendefinisikan sekolah pintar atau dikenali sebagai Sekolah Bestari sebagai institusi pendidikan yang diciptakan semula secara sistematik dari segi amalan pengajaran dan pembelajaran di mana pengurusan sekolah menyediakan kanak-kanak dalam zaman maklumat dan juga untuk mempromosikan matlamat Falsafah Pendidikan Kebangsaan.

Menurut Ghavifekr et al. (2016), ini juga merupakan anjakan ke-7 dalam Pelan Pembangunan Pendidikan Malaysia (2013-2025) yang menyatakan hasrat Kementerian dalam memanfaatkan TMK untuk meningkatkan kualiti pembelajaran berkualiti di seluruh Malaysia. Anjakan ke-7 dalam Pelan Pembangunan Pendidikan Malaysia (2013-2025) memberi tumpuan kepada penyediaan akses internet dan persekitaran maya, menambahkan kandungan dalam talian untuk perkongsian amalan terbaik serta memaksimumkan penggunaan TMK bagi pembelajaran jauh dan pembelajaran kadar kendiri. Dengan penggunaan TMK dalam PdPc, secara tidak langsung akan membantu dan memudahkan pengajaran berkualiti guru tanpa mengira lokasi atau tahap kemahiran murid.

Menurut Boo dan Leong (2016), pendidik memainkan peranan penting dalam menghadapi cabaran besar dalam pendidikan Matematik terutamanya dalam mengintegrasikan perisian pendidikan dinamik ke dalam PdPc untuk membantu menyediakan sumber pembelajaran yang berguna kepada pelajar. Cabaran lebih kompleks dalam Matematik di mana guru Matematik perlu mengimbangkan penggunaan pemikiran, kertas dan pensel serta alat TMK dalam aktiviti pengajaran dan penilaian yang melibatkan konsep Matematik yang abstrak dan sukar difahami oleh pelajar (Boo \& Leong 2016). Parrot dan Leong (2018) turut menyatakan bahawa dengan kemajuan TMK kini, amat mustahil untuk mengelakkan kesan TMK dalam penyelesaian masalah Matematik. Penggunaan TMK juga menyumbang kepada refleksi Matematik, pengenalpastian masalah dan membuat keputusan. Dengan adanya bimbingan dari guru Matematik, pelajar daripada tahap yang berbeza dapat menggunakan alat ini untuk menyokong dan memperluas penaakulan Matematik dan penentuan akal Matematik, meningkatkan pemahaman dalam konteks penyelesaian masalah di samping meningkatkan kemahiran komputasi (Parrot \& Leong 2018).

Teknologi dan kompetensi guru dalam penggunaan teknologi ialah elemen penting dalam meningkatkan kualiti guru (Donkor 2018). Untuk meningkatkan kualiti guru, program pendidikan guru telah dibentuk semula dan memperkasakan kualiti guru dengan kursus-kursus yang menerapkan penggunaan pelbagai teknologi dalam pengajaran. Guru dalam perkhidmatan harus bersedia untuk mengintegrasikan teknologi maklumat dan komunikasi (TMK) ke dalam amalan pembelajaran dan 
pemudahcaraan (PdPc) dalam kelas. Menurut Zolkefli, Osman dan Saidon (2017), anjakan paradigma ini memberi impak yang besar dalam hubungan guru dan pelajar, pelajar dan pelajar serta pelajar dan bahan pembelajaran. Penggunaan teknologi bersama dengan kualiti isi kandungan yang tinggi, pedagogi dan reka bentuk pengajaran boleh menambah baik pengalaman pembelajaran dan kesannya di mana pengajaran dan pembelajaran semakin memberi impak dalam sistem pendidikan masa kini.

\section{Pernyataan Masalah}

Teknologi merupakan satu kemahiran yang penting dalam tenaga kerja. Pelajar yang teknologi 'savvy' sering mempunyai peluang yang lebih baik untuk mendapatkan pekerjaan dan menjadi menjadi cemerlang dalam karier mereka. Walau bagaimanapun, tugas mengintegrasikan TMK ke dalam pengajaran bilik darjah terutamanya subjek Matematik dengan cara yang bermakna dan canggih masih mencabar. Walaupun bilik darjah mempunyai akses kepada teknologi, terdapat beberapa keadaan yang mempengaruhi pelaksanaan teknologi di bilik darjah seperti infrastruktur yang tidak lengkap, teknologi yang tidak mencukupi, pembangunan profesional yang berkesan, keberkesanan kendiri guru dan persepsi guru. (Ravendran \& Daud 2019).

NCTM (2000) telah mengetengahkan enam prinsip dalam membentuk asas yang penting dalam peningkatan pembelajaran Matematik, iaitu perkongsian (equity), kurikulum (curriculum), pengajaran (teaching), pembelajaran (learning), pentaksiran (assessment) dan teknologi (technology). NCTM (2000) menekankan kepentingan dan peranan guru serta integrasi TMK dalam PdPc Matematik untuk meningkatkan kualiti PdPc Matematik. Justeru, untuk memudahkan proses ini, adalah penting untuk menitikberatkan kepercayaan dan persepsi guru tentang program baru dari komputer bagi menyokong guru-guru dalam menangani cabaran integrasi teknologi. NCTM (2015) menyatakan bahawa guru yang efektif mengoptimumkan kegunaan teknologi untuk mengembangkan pemahaman pelajar, merangsang minat mereka dan meningkatkan penguasaan mereka dalam Matematik. Namun, bukan semua guru menggunakan teknologi dengan cara yang sesuai sejajar dengan hasrat NCTM. Menurut Mcculloch et al. (2018), ramai guru Matematik hanya menggunakan teknologi sebagai alat pengiraan yang mudah, penyimpanan data dan paparan statistik. Mereka melihat teknologi sebagai kaedah yang tidak mungkin dapat membantu pelajar dalam proses pembelajaran.

Kajian Aslan dan Chang (2016) menunjukkan guru sering menggunakan kemahiran TMK asas, contohnya menggunakan Powerpoint dan projektor untuk pembentangan. Mereka jarang mengintegrasikan teknologi dalam PdPc Matematik. Dengan kata yang lain, kecekapan mereka adalah terhad kepada kemahiran asas TMK dan tidak berminat untuk mengintegrasikan kemahiran TMK ke dalam amalan pengajaran mereka. Laporan oleh Kementerian Pendidikan Malaysia (2017) mendakwa bahawa kira-kira $80 \%$ guru menghabiskan kurang dari satu jam seminggu untuk mengintegrasikan TMK dalam pengajaran. Begitu juga laporan Pertubuhan Pendidikan, Saintifik dan Kebudayaan PBB (UNESCO) mendedahkan bahawa integrasi TMK guru di sekolah-sekolah Malaysia kurang menekankan penggunaan aplikasi teknologi sebagai alat pengajaran.

Pada tahun 2017, tiga belas daripada 212 buah sekolah rendah dari Wilayah Persekutuan Semenanjung Malaysia dianugerahkan 5 bintang. Educational Techonology Division of Malaysia (2017) telah mengesahkan senarai sekolah dengan tahap integrasi TMK yang berlainan, dari 1 bintang (terendah) hingga 5 bintang (tertinggi) untuk menggambarkan tahap pelaksanaan integrasi TMK di setiap sekolah berdasarkan SSQS(Smart School Qualification Standard). Penilaian ini mempunyai 4 dimensi utama, iaitu penggunaan TMK, modal insan, aplikasi dan infrastruktur. Oleh sebab hanya beberapa sekolah rendah yang menerima pengiktirafan 5-bintang, adalah penting untuk meneroka mengapa sekolahsekolah tertentu lebih menonjol daripada yang lain untuk integrasi TMK dalam pengajaran. (Razak, Jalil \& Ismail, 2019).

Pelbagai kajian (Apeanti, 2016; Bozkurt, 2016; Donkor, 2018; Mailizar, 2018; Mensah, 2018; Putrawangsa \& Hasanah, 2018; Stein, Gurevich \& Gorev, 2020) tentang penggunaan teknologi dalam PdPc Matematik telah dijalankan di luar negara, namun tidak banyak kajian yang dilakukan di negara 
Malaysia yang berkaitan dengan pendidikan Matematik sekolah rendah. Justeru, kajian ini bertujuan untuk mengkaji pengetahuan TMK guru Matematik sekolah rendah.

Secara khususnya, kajian ini bertujuan untuk menjawab persoalan kajian yang berikut:

I. Apakah pengetahuan TMK yang dimiliki oleh guru Matematik sekolah rendah dan penggunaannya dalam PdPc?

Kajian ini membahagikan pengetahuan guru kepada dua domain, iaitu pengetahuan TMK guru dan pengetahuan penggunaan TMK guru dalam PdPc.

\section{Kerangka Konseptual}

Dalam kajian ini, pengkaji menggunakan konstruk pengetahuan kerangka TPACK. Pelbagai kajian yang menunjukkan bahawa guru yang berkebolehan dari segi teknologi dan pedagogi lebih bersedia menggunakan TMK dalam PdPc (Darling-Aduana \& Heinrich, 2018; Maican, Cazan, Lixandroiu \& Dovleac, 2019; Suárez-Rodríguez, Almerich, Orellana, \& Díaz-García, 2018; Vongkulluksn, Xie, \& Bowman, 2018). Justeru, seseorang guru harus menjadi pakar dalam subjek dan pedagogi serta pengguna teknologi yang kompeten (Luik, Taimalu, \& Suviste, 2018).

Kerangka TPACK dibina lanjutan daripada konstruk pengetahuan pedagogi kandungan (PCK) oleh Shulman (1986). Kerangka ini mengenal pasti beberapa ciri untuk pengajaran. Beliau mendefinisikan pengetahuan pedagogi kandungan sebagai campuran kandungan dan pedagogi dalam pemahaman sesuatu topik, masalah, isu, perwakilan dan disesuaikan dengan pelbagai minat dan kemampuan pelajar dan pembentangan untuk instruksi. Koehler dan Mishra (2006) mengubah kerangka PCK dengan menambahkan pengetahuan mengenai integrasi teknologi di mana guru memahami bagaimana teknologi diterapkan dalam pengajaran subjek tertentu. Hasilnya, kerangka TPACK merangkumi tujuh jenis pengetahuan, iaitu pengetahuan teknologi (TK), pengetahuan pedagogi (PK), pengetahuan kandungan (CK), pengetahuan pedagogi kandungan (PCK), pengetahuan teknologi pedagogi (TPK), pengetahuan teknologi kandungan (TCK) dan pengetahuan teknologi pedagogi kandungan (TPACK). Rajah 1 di bawah menunjukkan model TPACK Koehler dan Mishra (2006) di mana tiga komponen utama saling terpadu di antara satu sama lain. Gabungan ketiga-tiga domain pengetahuan itu pula menghasilkan pengetahuan TPACK.

Rajah 1: Komponen TPACK.

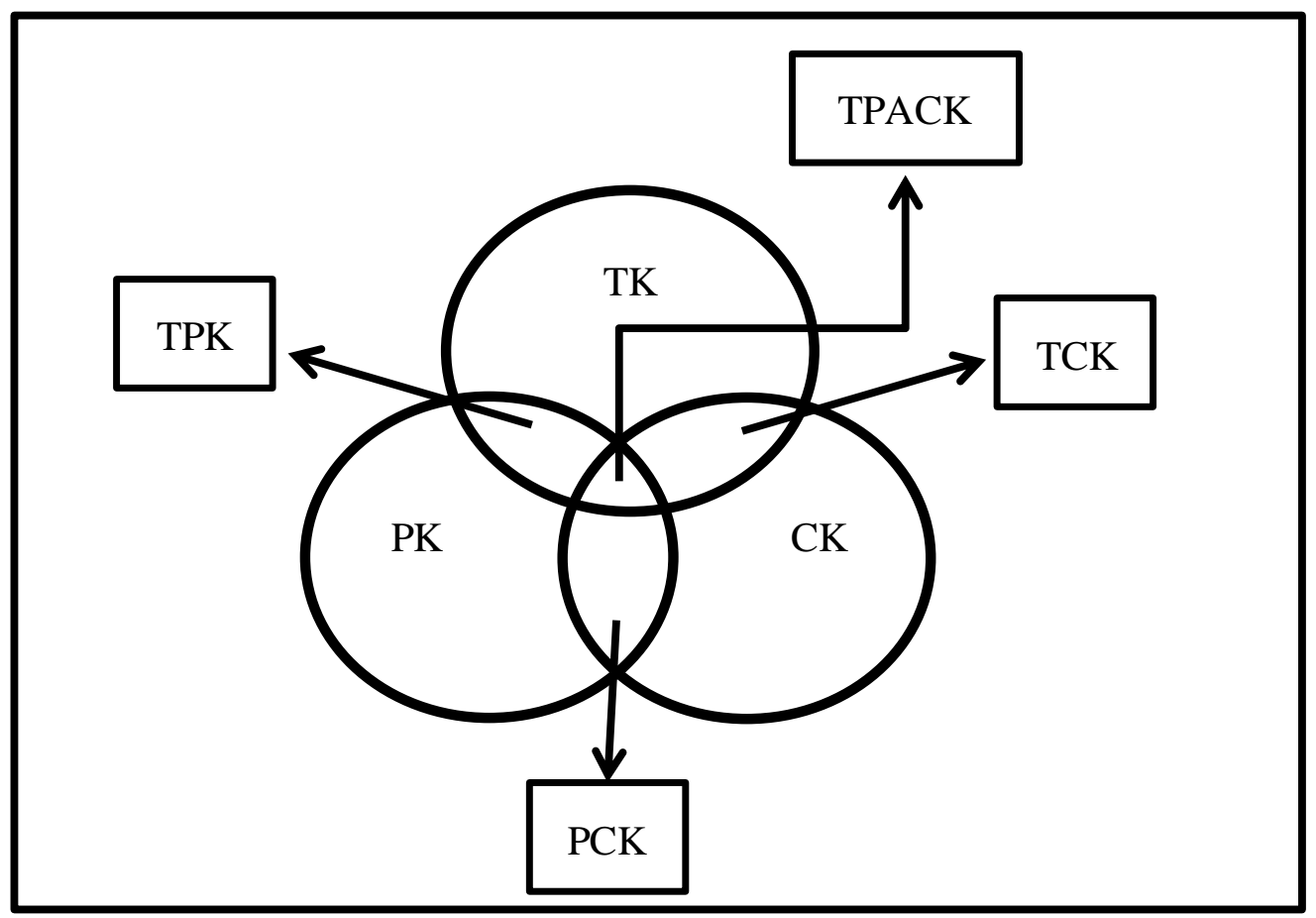


Kurt (2018) mendefinisikan setiap konstruk TPACK seperti yang ditunjukkan dalam Jadual 1.

\section{Jadual 1: Definisi Konstruk TPACK}

\begin{tabular}{|c|c|}
\hline Konstruk TPACK & Definisi \\
\hline $\begin{array}{l}\text { Pengetahuan Teknologi } \\
\text { (TK) }\end{array}$ & $\begin{array}{l}\text { Pengetahuan tentang cara menggunakan perkakasan dan perisian } \\
\text { TMK. }\end{array}$ \\
\hline $\begin{array}{l}\text { Pengetahuan Kandungan } \\
\text { (CK) }\end{array}$ & Pengetahuan tentang kandungan subjek \\
\hline $\begin{array}{l}\text { Pengetahuan Pedagogi } \\
\text { (PK) }\end{array}$ & $\begin{array}{l}\text { Pengetahuan mengenai kaedah dan proses pengajaran seperti } \\
\text { pengurusan bilik darjah, penilaian, perkembangan rancangan } \\
\text { pengajaran. }\end{array}$ \\
\hline $\begin{array}{l}\text { Pengetahuan Pedagogi } \\
\text { Kandungan (PCK) }\end{array}$ & $\begin{array}{l}\text { Pengetahuan mempersembahkan pengetahuan kandungan dan } \\
\text { menggunakan strategi pedagogi supaya pelajar lebih memahami } \\
\text { sesuatu isi atau topik (Shulman 1986). }\end{array}$ \\
\hline $\begin{array}{l}\text { Pengetahuan Teknologi } \\
\text { Kandungan (TCK) }\end{array}$ & $\begin{array}{l}\text { Pengetahuan tentang penggunaan teknologi untuk mewakili dan } \\
\text { mereka kandungan dengan pelbagai cara tanpa } \\
\text { mempertimbangkan pengajaran. }\end{array}$ \\
\hline $\begin{array}{l}\text { Pengetahuan Teknologi } \\
\text { Pedagogi (TPK) }\end{array}$ & $\begin{array}{l}\text { Pengetahuan tentang kewujudan dan spesifikasi pelbagai } \\
\text { teknologi untuk menyediakan pendekatan pengajaran tanpa } \\
\text { merujuk kepada kandungan subjek }\end{array}$ \\
\hline $\begin{array}{lr}\text { Pengetahuan } & \text { Teknologi } \\
\text { Pedagogi } & \text { Kandungan } \\
\text { (TPCK) } & \end{array}$ & $\begin{array}{l}\text { Pengetahuan menggunakan pelbagai teknologi untuk mengajar, } \\
\text { mewakili dan memudahkan pembentukan pengetahuan mengenai } \\
\text { kandungan subjek tertentu }\end{array}$ \\
\hline
\end{tabular}

Angeli dan Valanides (2009) mengadaptasi TPACK menjadi ICT-TPCK melalui interaksi lima bidang. Mereka menamakan semula domain teknologi sebagai Teknologi Maklumat dan Komunikasi (ICT) serta menambah dua domain pengetahuan, iaitu pengetahuan pelajar dan pengetahuan mengenai konteks di mana pembelajaran berlaku dalam interaksi lima bidang tersebut. Oleh itu, Angeli dan Valanides (2009) membentangkan lima domain pengetahuan yang diperlukan oleh guru semasa mereka mengintegrasikan TMK dalam pengajaran, iaitu pengetahuan kandungan, pengetahuan pedagogi, pengetahuan pelajar, pengetahuan konteks dan pengetahuan mengenai TMK seperti dalam Rajah 2.

Rajah 2: ICT-TPCK (Angeli \& Valanides 2009)

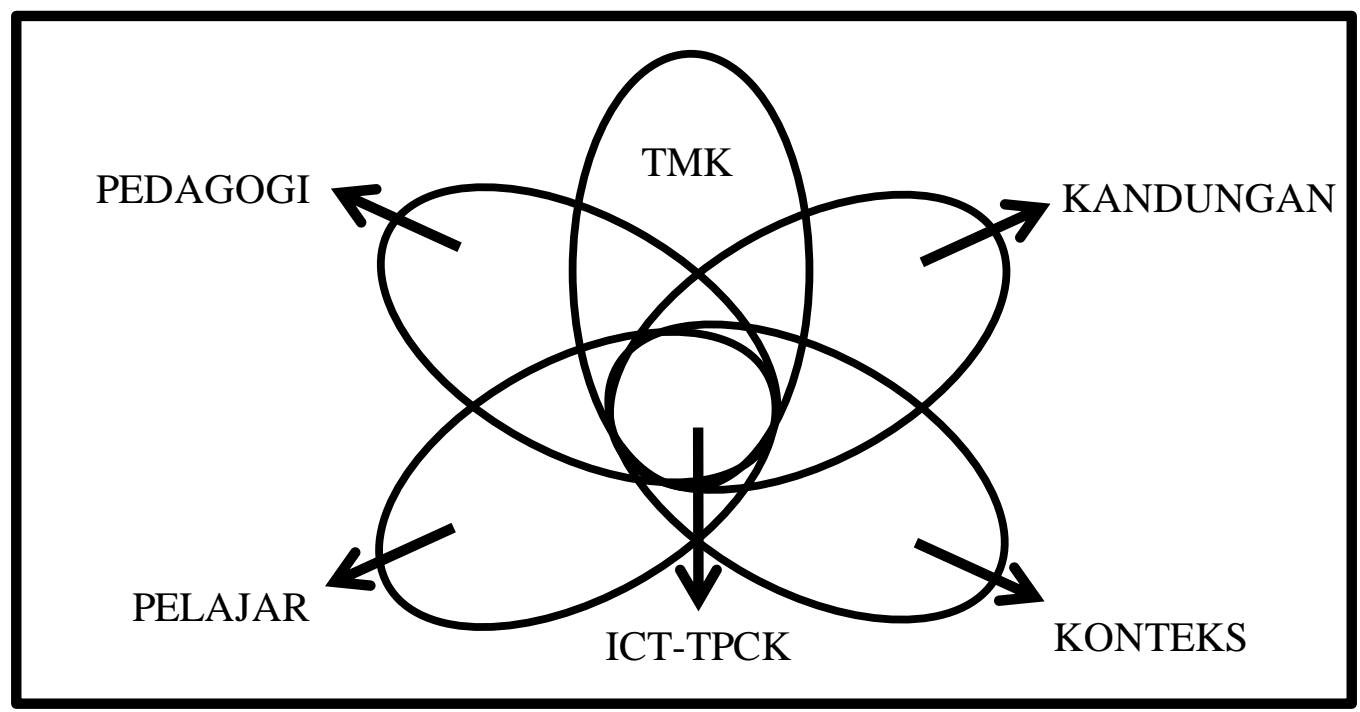

Kedua-dua model (model TPACK dan model ICT-TPCK) berkongsi beberapa elemen prinsip yang sama. Pertama, mereka menekankan penggunaan pelbagai teknologi digital dan kemampuan mereka dalam pengajaran dan pembelajaran. Ini memerlukan guru untuk memahami TMK secara mendalam untuk mengaplikasikannya dengan berkesan dalam bilik darjah serta menyedari kepentingan TMK dalam membantu guru untuk mencapai objektif pengajaran dan pembelajaran. Kedua, integrasi TMK 
dalam pengajaran memerlukan guru memahami kewujudan pelbagai alat TMK dan kemampuan pedagogi alat-alat TMK tersbeut (Angeli \& Valanides 2009; Mishra \& Koehler 2006). Yang terakhir, kedua-dua model ini juga menekankan pengetahuan strategi pedagogi dan kemampunan guru untuk mengaplikasikan strategi tersebut dalam penggunaan TMK untuk tugasan pembelajaran atau kandungan tertentu.

Berdasarkan kedua-dua model tersebut, pengkaji telah mengklasifikasikan konstruk pengetahuan yang dikaji dalam kajian ini seperti berikut. Pengkaji telah menggunakan definisi Angeli dan Valanides (2009) untuk menentukan pengetahuan TMK yang merangkumi cara mengendalikan komputer dan cara menggunakan pelbagai alat atau perisian TMK untuk menyelesaikan masalah.

Pengetahuan TMK yang digunakan dalam pengajaran adalah kompleks dan merupakan cabaran dalam mengembangkan definisi ringkas mengenai konsep ini. Handal et al. (2013) menggunakan model TPCK untuk mengkaji tentang pengetahuan guru Matematik sekolah menengah melalui pentadbiran instrumen yang dikenali TPCK-M (Pengetahuan Teknologi Pedagogi Kandungan Matematik) yang terdiri daripada tiga konstruk berdasarkan teori utama, iaitu pengetahuan teknologi kandungan (TCK), pengetahuan teknologi pedagogi (TPK) dan pengetahuan teknologi pedagogi kandungan (TPCK). Instrumen pengetahuan guru tentang penggunaan TMK dalam pengajaran terdiri daripada TCK, TPK dan TPCK yang kemudiannya disusun semula sebagai pengetahuan TMK kandungan (ICT-CK), pengetahuan TMK pedagogi (ICT-PK) dan pengetahuan TMK pedagogi kandungan (ICT-PCK).

Menurut Çetin dan Erdoğan (2018), adalah mustahak bahawa guru mempunyai pengetahuan teknologi dalam menggunakan program teknologi atau mempunyai pengetahuan tentang mana-mana topik Matematik dalam bidang. Contohnya, guru mempunyai sesuatu pengetahuan, namun tidak dapat menerangkan dengan kaedah dan teknik yang sesuai, atau jika guru dapat membuat persembahan yang sesuai tetapi tidak berapa mengetahui topik tersebut. Baharuldin et al. (2019) menyatakan bahawa TPACK ialah kerangka yang berkesan dalam menguji integrasi TMK guru berdasarkan pengetahuan teknologi, pengetahuan pedagogi dan pengetahuan kandungan. Çetin dan Erdoğan (2018) juga menyokong pernyataan di atas dengan berhujah bahawa TPACK merupakan asas kepada proses PdPc yang memerlukan guru menguasai pengetahuan tentang cara untuk membantu pelajar dalam menghadapi cabaran dan bagaimana teknologi membantu menyelesaikan masalah serta menstruktur dan memperkukuhkan pengetahuan awal pelajar.

\section{Metod Kajian}

\section{Reka Bentuk Kajian}

Reka bentuk kajian ini berbentuk tinjauan. Ia bertujuan untuk mengkaji pengetahuan TMK dan pengetahuan penggunaan TMK guru Matematik dalam PdPc sekolah rendah. Menurut Seng et al. (2018), kaedah penyelidikan tinjauan sangat berguna untuk menghasilkan data kuantitatif yang dapat digunakan untuk membuat kenyataan tentang sesuatu populasi secara umum. Kajian jenis tinjauan juga sering digunakan dalam penyelidikan teknologi maklumat dan penggunaan komputer (Seng et al. 2018). Sheila (2016) berhujah bahawa kaedah jenis tinjauan adalah berdasarkan persoalan atau hipotesis kajian di mana ia menentukan atau menyatakan kewujudan hubungan antara pemboleh ubah dan ciri pemboleh ubah seperti bentuk dan taburan untuk menjawab persoalan kajian. Soal selidik diberikan untuk mendapatkan respon responden kajian mengenai pengetahuan TMK dan pengetahuan penggunaan TMK guru Matematik dalam PdPc sekolah rendah.

\section{Responden Kajian}

Populasi yang terlibat dalam kajian ini adalah tujuh puluh lapan orang guru yang mengajar mata pelajaran Matematik di sekolah A, B dan C di zon Sentul, Kuala Lumpur. Berdasarkan saiz sampel ideal yang dikemukakan oleh Qualtrics (2020), sampel kajian yang sesuai adalah enam puluh lima orang responden. Justeru, kajian ini menggunakan kaedah pensampelan rawak mudah yang hanya melibatkan enam puluh lima orang guru Matematik. Guru-guru di sekolah-sekolah ini dipilih sebagai 
responden kajian kerana sekolah ini mempunyai kemudahan TMK yang mudah diakses dan boleh digunakan untuk menjalankan PdPc di dalam bilik darjah. Seng et al. (2018) turut menyatakan adalah penting untuk mendapatkan pendapat guru-guru mengenai penggunaan alat TMK dalam bilik darjah supaya penambahbaikan dapat dilakukan untuk mengintegrasikan TMK ke dalam PdPc selari dengan era teknologi moden.

\section{Instrumen Kajian}

Soal selidik telah diadaptasi daripada kajian Mailizar dan Fan (2020) sebagai instrumen untuk mengumpul data untuk menjawab persoalan kajian yang telah ditetapkan dalam kajian ini. Soal selidik yang digunakan dalam kajian ini merangkumi dua bahagian, iaitu latar belakang demografi guru dan pengetahuan guru. Bahagian pengetahuan guru berkaitan dengan TMK akan merujuk kepada definisi yang dikemukakan oleh Angeli dan Valanides (2009) seperti yang dibahaskan sebelumnya di bahagian kerangka konseptual. Dari segi pengetahuan guru mengenai penggunaan TMK dalam PcPc pula, kajian ini merujuk kepada Mishra dan Koehler's TPACK (2006).

Dalam borang soal selidik mengandungi tujuh bahagian. Instrumen ini tidak perlu responden kajian untuk mengisi maklumat peribadi responden kajian seperti nama dan nombor telefon. Terdapat 36 pernyataan atau item yang diadaptasi daripada kajian Mailizar dan Fan (2020) yang mengkaji tentang pengetahuan TMK guru dan pengetahuan penggunaan TMK guru dalam PdPc Matematik. Skor untuk setiap item ditentukan oleh tindak balas responden kajian dalam skala Likert 5 mata iaitu $1=$ Sangat Tidak Setuju, 2 = Tidak Setuju, 3 =Sederhana, 4 = Setuju, 5 = Sangat Setuju. Item-item dalam soal selidik ini dibina mengikut skala Likert kerana Skala Likert membolehkan pengkaji mendapatkan maklum balas atau respons yang tepat daripada responden kajian. Seng et al. (2018) juga menyatakan bahawa Skala Likert digunakan kerana ia boleh ditadbir dengan mudah dan cuma memerlukan sedikit masa untuk menerima maklum balas.

\section{Kesahan dan Kebolehpercayaan}

Kesahan dan kebolehpercayaan ialah dua ciri terpenting dan asas dalam penilaian mana-mana instrumen pengukuran atau alat untuk penyelidikan yang baik. Menurut Kumar (2017), kesahan berkaitan dapatan kajian yang dapat mengukur apa yang sepatutnya diukur oleh instrumen, dan seberapa baik instrumen tersebut melakukannya. Kebolehpercayaan berkaitan dengan kepercayaan yang dapat dimiliki seseorang dalam data yang diperoleh daripada penggunaan instrumen, iaitu sejauh mana alat pengukur mengawal kesalahan rawak (Kumar, 2017).

Dalam kajian ini, pengkaji telah merujuk kepada item-item soal selidik daripada kajian-kajian lepas (Mailizar \& Fan, 2020) yang mempunyai nilai Cronbach's Alpha yang agak tinggi, iaitu 0.974. Nilai yang tinggi ini menunjukkan item-item dalam soal selidik tersebut mempunyai kebolehpercayaan yang tinggi. Kesahan kandungan digunakan untuk menilai kesahan soal selidik. Kesahan kandungan adalah berdasarkan pada kerangka konseptual serta instrumen yang ada. Pengkaji juga telah berbincang dengan dua orang guru berpengalaman dalam mengajar Matematik dan seorang guru TMK di sekolah A bagi mendapatkan pandangan mereka tentang aspek-aspek yang boleh dikaji dalam kajian tinjauan. Langkah ini turut membantu meningkatkan kesahan dan kebolehpercayaan kajian ini. Pengkaji juga mendapatkan pandangan dan maklumat daripada guru-guru tersebut berkaitan pernyataan yang dikemukakan dalam soal selidik.

\section{Prosedur Analisis Data}

Data kuantitatif yang dikumpulkan melalui soal selidik menggambarkan pengetahuan TMK dan pengetahuan penggunaan TMK guru Matematik dalam PdPc sekolah rendah. Menurut Mailizar (2018), dua langkah penting dalam penganalisisan data melibatkan penyediaan data untuk dianalisis dan melakukan analisis data. Untuk menganalisis data, pertama sekali, label skor numerik, pemilihan program statistik yang sesuai, memasukkan data ke dalam perisian yang telah dipilih seterusnya mengemas dan memperhitungkan nilai yang hilang. Langkah kedua ialah melakukan analisis data yang merangkumi analisis statistik deskriptif untuk menjawab persoalan kajian (Mailizar, 2018). 
DOI: https://doi.org/10.47405/mjssh.v5i11.546

Data-data yang dikumpulkan akan diproses dengan menggunakan perisian statistik SPSS (Statistical Package For Social Sciences) versi 25. Semua respons mengenai pengetahuan guru akan dikodkan dalam skala Likert 5 mata. Analisis statistik deskriptif digunakan untuk menjawab persoalan kajian. Bagi setiap pernyataan yang dikemukakan, disediakan lima cadangan jawapan untuk dipilih oleh responden. Pengelasan skala adalah seperti dalam Jadual 2.

Jadual 2: Pengkelasan Skala

\begin{tabular}{cc}
\hline Skala & Catatan \\
\hline 1 & Sangat tidak setuju \\
2 & Tidak setuju \\
3 & Sederhana \\
4 & Setuju \\
5 & Sangat setuju \\
\hline
\end{tabular}

\section{Hasil Kajian}

\section{Pengetahuan TMKGuru}

Hasil dapatan daripada Jadual 3 menunjukkan kekerapan skor skala dan peratusan pengetahuan TMK guru termasuklah pengetahuan mengenai perkakasan TMK, pengetahuan tentang perisian umum, pengetahuan mengenai perisian Matematik dan pengetahuan mengenai sumber dalam talian. Daripada jadual di atas, dapat diketahui bahawa majoriti responden, iaitu sebanyak 30 orang responden $(46.2 \%)$ yang sederhana dalam penggunaan kalkulator grafik. Peratusan yang tinggi, iaitu sebanyak $63.1 \%$ responden dengan bilangan 41 orang responden didapati setuju bahawa mereka memahami cara menggunakan tablet dan peranti mudah alih. Bagi penggunaan komputer dan komputer riba pula, 37 orang responden dengan peratusan $56.9 \%$ setuju bahawa mereka boleh menggunakannya.

Jadual 3: Kekerapan skor skala dan peratusan tentang pengetahuan TMK guru

\begin{tabular}{|c|c|c|c|c|c|}
\hline Item & $\begin{array}{c}\text { Sangat } \\
\text { tidak } \\
\text { setuju } \\
\end{array}$ & $\begin{array}{l}\text { Tidak } \\
\text { setuju }\end{array}$ & Sederhana & Setuju & $\begin{array}{l}\text { Sangat } \\
\text { setuju }\end{array}$ \\
\hline \multicolumn{6}{|c|}{ Pengetahuan Perkakasan TMK } \\
\hline Kalkulator grafik & $\begin{array}{c}15 \\
(7.7 \%)\end{array}$ & $\begin{array}{c}11 \\
(16.9 \%)\end{array}$ & $\begin{array}{c}30 \\
(46.2 \%)\end{array}$ & $\begin{array}{c}16 \\
(24.6 \%)\end{array}$ & $\begin{array}{c}3 \\
(4.6 \%)\end{array}$ \\
\hline Tablet / Peranti Mudah Alih & $\begin{array}{c}0 \\
(0 \%)\end{array}$ & $\begin{array}{c}0 \\
(0 \%)\end{array}$ & $\begin{array}{c}14 \\
(21.5 \%)\end{array}$ & $\begin{array}{c}41 \\
(63.1 \%)\end{array}$ & $\begin{array}{c}10 \\
(15.4 \%)\end{array}$ \\
\hline Komputer/komputer riba & $\begin{array}{c}0 \\
(0 \%)\end{array}$ & $\begin{array}{c}0 \\
(0 \%)\end{array}$ & $\begin{array}{c}10 \\
(15.4 \%)\end{array}$ & $\begin{array}{c}37 \\
(56.9 \%)\end{array}$ & $\begin{array}{c}18 \\
(27.7 \%)\end{array}$ \\
\hline \multicolumn{6}{|c|}{ Pengetahuan Perisian Umum } \\
\hline $\begin{array}{l}\text { Perisian pemprosesan perkataan } \\
\text { (contoh: Microsoft Word) }\end{array}$ & $\begin{array}{c}0 \\
(0 \%)\end{array}$ & $\begin{array}{c}0 \\
(0 \%)\end{array}$ & $\begin{array}{c}22 \\
(33.8 \%)\end{array}$ & $\begin{array}{c}37 \\
(56.9 \%)\end{array}$ & $\begin{array}{c}6 \\
(9.2 \%)\end{array}$ \\
\hline $\begin{array}{l}\text { Perisian persembahan (contoh: } \\
\text { Microsoft PowerPoint) }\end{array}$ & $\begin{array}{c}0 \\
(0 \%)\end{array}$ & $\begin{array}{c}0 \\
(0 \%)\end{array}$ & $\begin{array}{c}29 \\
(44.6 \%)\end{array}$ & $\begin{array}{c}32 \\
(49.2 \%)\end{array}$ & $\begin{array}{c}4 \\
(6.2 \%)\end{array}$ \\
\hline $\begin{array}{l}\text { Perisian persembahan dalam } \\
\text { talian (contoh: Prezi) }\end{array}$ & $\begin{array}{c}13 \\
(20 \%)\end{array}$ & $\begin{array}{c}22 \\
(33.8 \%)\end{array}$ & $\begin{array}{c}19 \\
(29.2 \%)\end{array}$ & $\begin{array}{c}9 \\
(13.8 \%)\end{array}$ & $\begin{array}{c}2 \\
(3.1 \%)\end{array}$ \\
\hline $\begin{array}{l}\text { Perisian hamparan elektronik } \\
\text { (contoh: Microsoft Excel) }\end{array}$ & $\begin{array}{c}0 \\
(0 \%)\end{array}$ & $\begin{array}{c}3 \\
(4.6 \%)\end{array}$ & $\begin{array}{c}23 \\
(35.4)\end{array}$ & $\begin{array}{c}33 \\
(50.8 \%)\end{array}$ & $\begin{array}{c}6 \\
(9.2 \%)\end{array}$ \\
\hline $\begin{array}{l}\text { Perisian pemetaan minda } \\
\text { (contoh: Inspirasi) }\end{array}$ & $\begin{array}{c}45 \\
(69.2 \%)\end{array}$ & $\begin{array}{c}14 \\
(21.5 \%)\end{array}$ & $\begin{array}{c}6 \\
(9.2 \%)\end{array}$ & $\begin{array}{c}0 \\
(0 \%)\end{array}$ & $\begin{array}{c}0 \\
(0 \%)\end{array}$ \\
\hline $\begin{array}{l}\text { Perisian animasi (contoh: } \\
\text { Macromedia Flash) }\end{array}$ & $\begin{array}{c}54 \\
(83.1 \%)\end{array}$ & $\begin{array}{c}6 \\
(9.2 \%)\end{array}$ & $\begin{array}{c}5 \\
(7.7 \%)\end{array}$ & $\begin{array}{c}0 \\
(0 \%)\end{array}$ & $\begin{array}{c}0 \\
(0 \%)\end{array}$ \\
\hline $\begin{array}{l}\text { Perisian visualisasi tiga dimensi } \\
\text { (contoh: SketchUp) }\end{array}$ & $\begin{array}{c}29 \\
(44.6 \%) \\
\end{array}$ & $\begin{array}{c}28 \\
(43.1 \%) \\
\end{array}$ & $\begin{array}{c}5 \\
(7.7 \%) \\
\end{array}$ & $\begin{array}{c}3 \\
(4.6 \%) \\
\end{array}$ & $\begin{array}{c}0 \\
(0 \%) \\
\end{array}$ \\
\hline
\end{tabular}


DOI: https://doi.org/10.47405/mjssh.v5i11.546

\begin{tabular}{|c|c|c|c|c|c|}
\hline \multicolumn{6}{|c|}{ Pengetahuan Perisian Matematik } \\
\hline Perisian sistem algebra komputer & 37 & 27 & 1 & 0 & 0 \\
\hline \multicolumn{6}{|l|}{ Mathematica) } \\
\hline $\begin{array}{l}\text { Perisian geometri dinamik } \\
\text { (contoh: Geometer's Sketchpad } \\
\text { dan Cabri Geometrv) }\end{array}$ & $\begin{array}{c}26 \\
(40 \%)\end{array}$ & $\begin{array}{c}28 \\
(43.1 \%)\end{array}$ & $\begin{array}{c}8 \\
(12.3 \%)\end{array}$ & $\begin{array}{c}3 \\
(4.6 \%)\end{array}$ & $\begin{array}{c}0 \\
(0 \%)\end{array}$ \\
\hline $\begin{array}{lrr}\text { Perisian } & \text { Matematik } & \text { dinamik } \\
\text { (contoh: } & \text { GeoGebra } & \text { dan } \\
\text { Autograph) } & & \end{array}$ & $\begin{array}{c}52 \\
(80 \%)\end{array}$ & $\begin{array}{c}11 \\
(16.9 \%)\end{array}$ & $\begin{array}{c}2 \\
(3.1 \%)\end{array}$ & $\begin{array}{c}0 \\
(0 \%)\end{array}$ & $\begin{array}{c}0 \\
(0 \%)\end{array}$ \\
\hline $\begin{array}{l}\text { Perisian statistik (contoh: } \\
\text { Tinkerplots, Fathom dan SPSS) }\end{array}$ & $\begin{array}{c}48 \\
(73.8 \%)\end{array}$ & $\begin{array}{c}13 \\
(20 \%)\end{array}$ & $\begin{array}{c}1 \\
(1.5 \%)\end{array}$ & $\begin{array}{c}3 \\
(6 \%)\end{array}$ & $\begin{array}{c}0 \\
(0 \%)\end{array}$ \\
\hline \multicolumn{6}{|c|}{ Pengetahuan Sumber Atas Talian } \\
\hline $\begin{array}{l}\text { Aplikasi laman web (contoh: } \\
\text { Youtube dan Khan Academv) }\end{array}$ & $\begin{array}{c}0 \\
(\Omega \%)\end{array}$ & $\begin{array}{c}0 \\
(0 \%)\end{array}$ & 16 & $\begin{array}{c}43 \\
(67.7 \%)\end{array}$ & $\begin{array}{c}6 \\
(77 \%)\end{array}$ \\
\hline $\begin{array}{l}\text { Youtube dan Khan Academy) } \\
\text { Sistem nenourusan nembelaiaran }\end{array}$ & $(0 \%)$ & $(0 \%)$ & $\begin{array}{c}(24.6 \%) \\
13\end{array}$ & $\begin{array}{c}(67.7 \%) \\
40\end{array}$ & $\begin{array}{c}(7.7 \%) \\
12\end{array}$ \\
\hline $\begin{array}{l}\text { Sistem pengurusan pembelajaran } \\
\text { (contoh: Google Classroom) }\end{array}$ & $\begin{array}{c}0 \\
(0 \%)\end{array}$ & $\begin{array}{c}0 \\
(0 \%)\end{array}$ & $\begin{array}{c}13 \\
(20 \%)\end{array}$ & $\begin{array}{c}40 \\
(61.5 \%)\end{array}$ & $(18.5 \%)$ \\
\hline
\end{tabular}

Dalam aspek pengetahuan tentang perisian umum, dapat diketahui bahawa majoriti responden memberikan skala setuju dalam penguasaan pengetahuan, iaitu 56.9\% responden dalam perisian pemprosesan perkataan, $49.2 \%$ responden dalam perisian persembahan serta $50.8 \%$ responden dalam perisian hamparan elektronik. Hasil dapatan menunjukkan bahawa peratusan responden dalam menggunakan perisian pemprosesan perkataan adalah tinggi jika dibandingkan dengan perisian umum yang lain. Terdapat 22 orang responden dengan peratusan $33.8 \%$ tidak setuju bahawa mereka boleh menggunakan perisian persembahan dalam talian. Kebanyakan responden mencatat peratusan yang paling tinggi, iaitu sangat tidak bersetuju dalam menguasai cara penggunaan perisian pemetaan minda $(69.2 \%)$, perisian animasi $(83.1 \%)$ dan perisian visualisasi tiga dimensi $(44.6 \%)$.

Hasil kajian menunjukkan skor skala pengetahuan guru mengenai perisian Matematik adalah rendah. Jadual di atas menunjukkan 37 orang responden dengan peratusan 56.9\% sangat tidak setuju bahawa mereka dapat menggunakan perisian sistem algebra komputer. Bagi perisian geometri dinamik pula, terdapat 28 orang responden yang tidak setuju dengan penggunaannya. Peratusan yang tinggi, iaitu $80 \%$ responden dengan bilangan 52 orang responden yang didapati sangat tidak setuju dengan kemahiran mereka dalam menggunakan perisian Matematik dinamik. Terdapat 48 orang responden (73.8\%) memberikan skala sangat tidak bersetuju dalam cara penggunaan perisian statistik. Hasil menunjukkan peratusan pengetahuan guru mengetahui perisian Matematik yang agak tinggi pada skor skala sangat tidak bersetuju yang membuktikan guru tidak mempunyai pengetahuan langsung tentang perisian Matematik seperti Maple, Geometer's Sketchpad, Geogebra, SPSS dan lain-lain.

Bagi aspek pengetahuan sumber atas talian pula, dapatan dalam aspek ini membuktikan kebanyakan responden iaitu sebanyak 43 orang responden (67.7\%) bersetuju bahawa mereka tahu cara menggunakan aplikasi laman web seperti Youtube. Selain itu, 40\% responden dengan bilangan 40 orang responden juga memberikan skala setuju dalam kemahiran menggunakan sistem pengurusan pembelajaran seperti Google Classroom. Keseluruhannya, responden kajian didapati mempunyai pengetahuan dalam cara penggunaan perkakasan TMK, penggunaan sumber atas talian dan sesetengah perisian umum. Dapatan juga menunjukkan responden adalah kurang berpengetahuan dalam cara penggunaan perisian Matematik.

\section{Pengetahuan Guru Tentang Penggunaan TMK Dalam PdPc}

Dalam kajian ini, pengetahuan guru mengenai penggunaan TMK dalam PdPc terdiri daripada tiga komponen, iaitu pengetahuan TMK kandungan (ICT-CK), pengetahuan TMK pedagogi (ICT-PK) dan 
pengetahuan TMK pedagogi kandungan (ICT-PCK). Jadual 4 menunjukkan skor skala dan peratusan pengetahuan guru tentang penggunaan TMK dalam PdPc.

Jadual 4: Kekerapan Skor Skala dan Peratusan Tentang Pengetahuan Penggunaan Tmk dalam Pdpc

\begin{tabular}{|c|c|c|c|c|c|}
\hline Item & $\begin{array}{c}\text { Sangat } \\
\text { tidak } \\
\text { setuju } \\
\end{array}$ & $\begin{array}{l}\text { Tidak } \\
\text { setuju }\end{array}$ & Sederhana & Setuju & $\begin{array}{l}\text { Sangat } \\
\text { setuju }\end{array}$ \\
\hline \multicolumn{6}{|c|}{$\begin{array}{l}\text { Pengetahuan TMK Kandungan (ICT-CK) } \\
\end{array}$} \\
\hline Penggunaan TMK untuk mewakili idea & 0 & 6 & 35 & & 3 \\
\hline Matematik. & $(0 \%)$ & $(9.2 \%)$ & $(53.8 \%)$ & $(32.3 \%)$ & $(4.6 \%)$ \\
\hline $\begin{array}{lll}\text { Penggunaan } & \text { TMK } & \text { untuk }\end{array}$ & 0 & 11 & 38 & 12 & 4 \\
\hline menyampaikan proses Matematik. & $(0 \%)$ & $(16.9 \%)$ & $(58.5 \%)$ & $(18.5 \%)$ & $(6.2 \%)$ \\
\hline $\begin{array}{l}\text { Penggunaan } \quad \text { TMK untuk } \\
\text { menyelesaikan masalah Matematik. }\end{array}$ & $\begin{array}{c}1 \\
(1.5 \%)\end{array}$ & $\begin{array}{c}16 \\
(24.6 \%)\end{array}$ & $\begin{array}{c}40 \\
(61.5 \%)\end{array}$ & $\begin{array}{c}7 \\
(10.8 \%)\end{array}$ & $\begin{array}{c}1 \\
(1.5 \%)\end{array}$ \\
\hline $\begin{array}{l}\text { Penggunaan TMK untuk meneroka } \\
\text { idea Matematik }\end{array}$ & $\begin{array}{c}6 \\
(9.2 \%)\end{array}$ & $\begin{array}{c}32 \\
(49.2 \%)\end{array}$ & $\begin{array}{c}23 \\
(35.4 \%)\end{array}$ & $\begin{array}{c}3 \\
(4.6 \%)\end{array}$ & $\begin{array}{c}1 \\
(1.5 \%)\end{array}$ \\
\hline \multicolumn{6}{|c|}{ Pengetahuan TMK Pedagogi (ICT-PK) } \\
\hline $\begin{array}{l}\text { Penggunaan TMK dalam PdPc melalui } \\
\text { pelaksanaan pembelajaran langsung. }\end{array}$ & $\begin{array}{c}1 \\
(1.5 \%)\end{array}$ & $\begin{array}{c}10 \\
(15.4 \%)\end{array}$ & $\begin{array}{c}30 \\
(46.2 \%)\end{array}$ & $\begin{array}{c}23 \\
(35.4 \%)\end{array}$ & $\begin{array}{c}1 \\
(1.5 \%)\end{array}$ \\
\hline $\begin{array}{l}\text { Penggunaan TMK dalam PdPc melalui } \\
\text { pelaksanaan pembelajaran berasaskan } \\
\text { inkuiri. }\end{array}$ & $\begin{array}{c}1 \\
(1.5 \%)\end{array}$ & $\begin{array}{c}9 \\
(13.8 \%)\end{array}$ & $\begin{array}{c}37 \\
(56.9 \%)\end{array}$ & $\begin{array}{c}18 \\
(27.7 \%)\end{array}$ & $\begin{array}{c}0 \\
(0 \%)\end{array}$ \\
\hline $\begin{array}{l}\text { Penggunaan TMK dalam PdPc melalui } \\
\text { pelaksanaan pembelajaran berasaskan } \\
\text { projek. }\end{array}$ & $\begin{array}{c}1 \\
(1.5 \%)\end{array}$ & $\begin{array}{c}12 \\
(18.5 \%)\end{array}$ & $\begin{array}{c}39 \\
(60 \%)\end{array}$ & $\begin{array}{c}12 \\
(18.5 \%)\end{array}$ & $\begin{array}{c}1 \\
(1.5 \%)\end{array}$ \\
\hline $\begin{array}{l}\text { Penggunaan TMK dalam PdPc melalui } \\
\text { pelaksanaan pembelajaran berasaskan } \\
\text { penemuan. }\end{array}$ & $\begin{array}{c}1 \\
(1.5 \%)\end{array}$ & $\begin{array}{c}12 \\
(18.5 \%)\end{array}$ & $\begin{array}{c}41 \\
(63.1 \%)\end{array}$ & $\begin{array}{c}10 \\
(15.4 \%)\end{array}$ & $\begin{array}{c}1 \\
(1.5 \%)\end{array}$ \\
\hline $\begin{array}{l}\text { Penggunaan TMK dalam PdPc melalui } \\
\text { pelaksanaan pembelajaran kolaboratif. }\end{array}$ & $\begin{array}{c}1 \\
(1.5 \%)\end{array}$ & $\begin{array}{c}9 \\
(13.8 \%)\end{array}$ & $\begin{array}{c}36 \\
(55.4 \%)\end{array}$ & $\begin{array}{c}17 \\
(26.2 \%)\end{array}$ & $\begin{array}{c}2 \\
(3.1 \%)\end{array}$ \\
\hline \multicolumn{6}{|c|}{ Pengetahuan TMK Pedagogi Kandungan (ICT-PCK) } \\
\hline $\begin{array}{l}\text { Penggunaan TMK untuk mengajar } \\
\text { topik Matematik yang lebih senang } \\
\text { dipelajari ketika menggunakan } \\
\text { pendekatan pengajaran khusus. }\end{array}$ & $\begin{array}{c}3 \\
(4.6 \%)\end{array}$ & $\begin{array}{c}10 \\
(15.4 \%)\end{array}$ & $\begin{array}{c}38 \\
(58.5 \%)\end{array}$ & $\begin{array}{c}13 \\
(20 \%)\end{array}$ & $\begin{array}{c}1 \\
(1.5 \%)\end{array}$ \\
\hline $\begin{array}{l}\text { Penggunaan strategi yang } \\
\text { menggabungkan kandungan matematik, } \\
\text { TMK dan pendekatan pengajaran untuk } \\
\text { mengukuhkan pemahaman pelajar } \\
\text { dalam pembelajaran Matematik. }\end{array}$ & $\begin{array}{c}3 \\
(4.6 \%)\end{array}$ & $\begin{array}{c}14 \\
(21.5 \%)\end{array}$ & $\begin{array}{c}37 \\
(56.9 \%)\end{array}$ & $\begin{array}{c}10 \\
(15.4 \%)\end{array}$ & $\begin{array}{c}1 \\
(1.5 \%)\end{array}$ \\
\hline $\begin{array}{l}\text { Penggunaan TMK dalam PdPc untuk } \\
\text { memperkukuh kandungan Matematik } \\
\text { dan kaedah pengajaran. }\end{array}$ & $\begin{array}{c}2 \\
(3.1 \%)\end{array}$ & $\begin{array}{c}18 \\
(27.7 \%)\end{array}$ & $\begin{array}{c}35 \\
(53.8 \%)\end{array}$ & $\begin{array}{c}9 \\
(13.8 \%)\end{array}$ & $\begin{array}{c}1 \\
(1.5 \%)\end{array}$ \\
\hline $\begin{array}{l}\text { Penggunaan TMK untuk menjalankan } \\
\text { tugas-tugas autentik dalam pengajaran } \\
\text { Matematik melalui pembelajaran } \\
\text { berasaskan projek. }\end{array}$ & $\begin{array}{c}3 \\
(4.6 \%)\end{array}$ & $\begin{array}{c}24 \\
(36.9 \%)\end{array}$ & $\begin{array}{c}32 \\
(49.2 \%)\end{array}$ & $\begin{array}{c}5 \\
(7.7 \%)\end{array}$ & $\begin{array}{c}1 \\
(1.5 \%)\end{array}$ \\
\hline $\begin{array}{l}\text { Penggunaan TMK untuk mengajar } \\
\text { pelajar mengembangkan } \\
\text { penyelesaian masalah } \\
\text { melalui pematematik } \\
\text { inkuiri. }\end{array}$ & $\begin{array}{c}5 \\
(7.7 \%)\end{array}$ & $\begin{array}{c}17 \\
(26.2 \%)\end{array}$ & $\begin{array}{c}27 \\
(41.5 \%)\end{array}$ & $\begin{array}{c}15 \\
(23.1 \%)\end{array}$ & $\begin{array}{c}1 \\
(1.5 \%)\end{array}$ \\
\hline
\end{tabular}


Dalam aspek pengetahuan TMK kandungan, dapat diketahui bahawa majoriti responden hanya sederhana dalam menggunakan TMK dalam kemahiran Matematik, iaitu 53.8\% responden dalam perwakilan Matematik, 58.8\% responden dalam penyampaian proses Matematik serta $40 \%$ responden dalam penyelesaian masalah Matematik. Terdapat 32 orang responden dengan peratusan $49.2 \%$ tidak bersetuju bahawa mereka dapat menggunakan TMK dalam meneroka idea Matematik. Jadual turut menunjukkan majoriti responden adalah sederhana dalam menggunakan pengetahuan TMK pedagogi dalam PdPc melalui pelaksanaan pembelajaran langsung (46.2\%), pembelajaran berasaskan inkuiri (56.9\%), pembelajaran berasaskan projek $(60 \%)$, pembelajaran berasaskan penemuan $(63.1 \%)$ dan pembelajaran koperatif $(55.4 \%)$.

Selain itu, dapatan juga membuktikan kebanyakan responden adalah sederhana dalam menguasai pengetahuan TMK pedagogi kandungan. Sebanyak 38 orang responden $(58.5 \%)$ yang sederhana dalam menggunakan TMK untuk mengajar topik Matematik ketika menggunakan pendekatan pengajaran khusus. Terdapat $56.9 \%$ responden yang menyatakan mereka sederhana dalam menggunakan strategi yang menggabungkan kandungan Matematik, TMK dan pendekatan pengajaran. Untuk memperkukuh kandungan Matematik dan kaedah pengajaran, 35 orang responden dengan peratusan 53.8\% menyatakan bahawa mereka sederhana dalam menggunakan TMK dalam PdPc. Terdapat 32 orang responden $(49.2 \%)$ memberikan skala tiga dalam kemampuan mereka menggunakan TMK untuk menjalankan tugas-tugas autentik dalam pengajaran Matematik melalui pembelajaran berasaskan projek. Untuk mengembangkan kemahiran penyelesaian masalah Matematik melalui pembelajaran berasaskan inkuiri, $41.5 \%$ responden sederhana dalam menggunakan TMK. Nilai-nilai peratusan dalam jadual menunjukkan responden kajian kurang berpengetahuan dalam cara penggunaan TMK dalam PdPc.

\section{Perbincangan Kajian}

Menurut Mailizar (2018), kajian mengkaji pengetahuan TMK guru dalam PdPc telah mendapat perhatian yang khusus dalam dekad ini. Kajian sebegini adalah relevan untuk memahami dan meningkatkan integrasi teknologi digital di dalam kelas. Oleh sebab kajian ini lebih tertumpu pada pengetahuan TMK guru dan pengetahuan guru mengenai penggunaan TMK dalam PdPc, pengkaji telah menggunakan model yang dikemukakan oleh Anglei dan Valanides (2009) dan model Mishra dan Koehler's TPACK (2006) untuk mendefinisikan kedua-dua pengetahuan tersebut.

Hasil kajian membuktikan bahawa guru Matematik di sekolah A, B dan C mempunyai pengetahuan TMK dan pengetahuan penggunaan TMK dalam PdPc yang sederhana. Dalam aspek pengetahuan perkakasan TMK, dapatan menunjukkan bahawa pengetahuan guru mengenai kalkulator grafik adalah sangat rendah jika dibandingkan dengan tablet atau komputer riba. Dalam kajian Parrot dan Leong (2018), kajian mengenai kalkulator grafik dijalankan ke atas sekolah menengah di Malaysia dan penggunaan kalkulator grafik sesuai digunakan dalam penyelesaian masalah Matematik sekolah menengah. Justeru, tidak menghairankan bahawa jika bukan semua guru Matematik sekolah rendah yang mempunyai pengetahuan tentang kalkulator grafik dalam kajian ini. Pernyataan di atas juga disokong oleh Mailizar (2018) yang menyatakan bahawa hanya 25.5\% guru Matematik yang telah belajar cara menggunakan kalkulator grafik. Pada tahun 2019, Mazana, Montero dan Oyelere mengkaji tentang kesediaan guru dalam menggunakan TMK dalam PdPc, pengetahuan mengenai komputer dan komputer riba ialah $100 \%$ dan adalah tinggi berbanding dengan penggunaan tablet $(14.3 \%)$ dan smartphone (42.9\%). Dapatan kajian Mazana, Montero dan Oyelere (2019) adalah selari dengan dapatan kajian ini yang membuktikan bahawa peratusan kemahiran penggunaan komputer dan komputer riba adalah lebih tinggi daripada penggunaan tablet dan peranti mudah alih.

Selain daripada pengetahuan perkakasan TMK, pengkaji juga mengkaji tentang pengetahuan guru mengenai perisian umum dan perisian Matematik. Majoriti responden kajian melaporkan bahawa pengetahuan mereka mengenai perisian pemprosesan kata seperti Microsoft Word adalah yang tertinggi dan kemudian diikuti pengetahuan tentang perisian hamparan (Microsoft Excel) dan perisian persembahan (Microsoft Powerpoint). Tidak dapat dinafikan bahawa ketiga-tiga jenis perisian umum ini sering digunakan dan biasa digunakan dalam kerja di sekolah. Dapatan ini adalah sejajar dengan kajian Kazoka dan William (2016) dan Mailizar dan Fan (2020) yang membuktikan bahawa majoriti guru 
dapat menggunakan Microsoft Word. Walau bagaimanapun, pengetahuan guru mengenai perisian umum mungkin tidak mempunyai kesan yang signifikan terhadap integrasi ICT di bilik darjah matematik kerana perisian tersebut tidak mempunyai ciri untuk memudahkan pelajar membina pengetahuan matematik mereka (Mailizar \& Fan, 2020).

Hasil kajian menunjukkan bahawa pengetahuan responden kajian mengenai perisian umum adalah lebih tinggi daripada pengetahuan perisian Matematik. Dalam kajian ini, pengkaji meninjau pengetahuan guru tentang beberapa perisian Matematik seperti perisian Matematik Dinamik, Perisian Geometri Dinamik, Sistem Algebra Komputer dan perisian statistik. Menurut Zengin dan Tatar (2017), perisian Matematik seperti perisian Matematik Dinamik dapat memberi ruang kepada pelajar untuk memahami konsep dengan lebih baik dan mudah dengan visualisasi konsep, mewujudkan persekitaran pembelajaran yang menyenangkan dan menyeronokkan serta meningkatkan motivasi dan minat pelajar sehingga mempengaruhi prestasi pelajar secara positif. Dapatan kekerapan skor skala dan peratusan mengenai pengetahuan perisian Matematik yang agak rendah dalam kajian ini menunjukkan bahawa guru Matematik perlu meningkatkan pengetahuan mengenai perisian Matematik kerana dipercayai pengetahuan sedemikian memainkan peranan penting dalam merancang dan melaksanakan pelajaran Matematik berasaskan TMK di dalam kelas.

Aspek terakhir dalam pengetahuan TMK guru ialah pengetahuan mengenai sumber atas talian. Hasil dapatan menunjukkan guru mempunyai pengetahuan yang tinggi dalam aplikasi laman web seperti Youtube, Quizizz, Edpuzzle dan sistem pengurusan pembelajaran seperti Google Classroom. Menurut Osman (2020), Malaysia merekodkan carian fasa "Google Classroom" tertinggi di dunia membuktikan guru di negara Malaysia berdedikasi dan komited dalam tugas. Perkembangan yang positif ini jelas dilihat apabila ramai guru mampu menyediakan bahan pembelajaran digital mereka sendiri untuk PdPc atas talian seperti CikgooTube, kumpulan Telegram Google Classroom Malaysia dan Facebook Guru Perpustakaan dan Media (Hamzah, 2020).

Domain kedua yang dikaji dalam kajian ini ialah pengetahuan guru mengenai penggunaan TMK dalam PdPc. Hasil dapatan kajian menunjukkan guru mempunyai pengetahuan yang tidak mencukupi mengenai penggunaan TMK dalam PdPc. Dapatan kajian yang menunjukkan pengetahuan TMK Kandungan dan pengetahuan TMK pedagogi adalah lebih tinggi daripada pengetahuan TMK pedagogi kandungan seiring dengan dapatan Mailizar dan Fan (2020). Daripada hasil ini, jelas dilihat bahawa pengetahuan TMK pedagogi kandungan adalah lebih kompleks dan rumit daripada pengetahuan TMK kandungan dan pengetahuan TMK pedagogi. Oleh itu, guru merasa lebih sukar untuk memperoleh pengetahuan TMK pedagogi kandungan. Guru pra-perkhidmatan di Malaysia masih tidak membezakan PCK, TCK, TPK dan TPACK dengan jelas, menunjukkan guru pra-perkhidmatan tidak dapat membezakan antara domain yang berkaitan dengan teknologi dan PCK (Nordin \& Ariffin, 2016). Justeru, adalah penting untuk guru pra-perkhidmatan disediakan kursus yang berkaitan dan menguasai pengetahuan ini bagi menghadapi cabaran masa akan datang. Akhirnya, kajian ini menunjukkan pentingnya untuk melengkapkan guru Matematik sekolah rendah dengan pengetahuan TMK dan pengetahuan penggunaan TMK dalam PdPc melalui penyediaan kursus latihan yang menekankan pada hubungan antara kandungan pedagogi dan integrasi TMK dalam Matematik.

\section{Kesimpulan}

Kajian ini meninjau tentang pengetahuan guru Matematik di sekolah A, B dan C mengenai TMK dan pengetahuan guru mengenai TMK dalam PdPc. Hasil kajian menunjukkan bahawa sebahagian guru di ketiga-tiga sekolah tersebut masih tidak mempunyai pengetahuan yang cukup mengenai TMK terutamanya pengetahuan tentang perisian umum dan perisian Matematik. Pengetahuan penggunaan TMK dalam PdPc juga pada tahap yang sederhana di mana pengetahuan TMK kandungan dan pengetahuan TMK pedagogi adalah lebih baik daripada pengetahuan TMK pedagogi kandungan. Berdasarkan hasil kajian, adalah dicadangkan pengurusan sekolah boleh mengatur latihan dalam perkhidmatan secara berkala dalam kursus pengembangan profesional untuk guru. Dengan kursus yang dijalankan, diharapkan dapat meningkatkan kecekapan guru dan mengurangkan kegelisahan mereka dalam menggunakan TMK dalam PdPc. 


\section{Rujukan}

Angeli, C., \& Valanides, N. (2009). Epistemological and methodological issue for the conceptualization, development, and assessment of ICT-TPCK: Advance in technilogical pedagogical content knolwedge (TPCK). Computer \& Education, 52, 154-168.

Aslan, A. \& Chang, Z. (2016). Influencing factors and integration of ICT into teaching practices of pre-service and starting teachers. International Journal of Research in Education and Science, 2(2), 359-370.

Baharuldin, Z, Shahrir, J, Shahril, N.S. \& Sumaia, Z. (2019). The role of teacher readiness as a mediator in the development of TMK competency in Pahang Primary School. Journal of Educational Research and Indigeneous Studies, 2(1).

Boo, J.Y. \& Leong, K.E. (2016). Effect of using logo on pupils' learning in two-dimensional shapes. Malaysian Online Journal of Educational Technology, 4(3), 27-36.

Bozkurt, G. (2016). Mathematics teachers and ICT: Factors affecting pre-service use in school placements. International Journal of Research in Education and Science (IJRES), 2(2), 453-468.

Çetin, İ. \& Erdoğan, A. (2018). Development, validity and reliability study of technological pedagogical content knowledge (TPACK) efficiency scale for mathematics teacher candidates. International Journal of Contemporary Educational Research, 5(1), 50-62.

Darling-Aduana, J. \& Heinrich, C. (2018). The role of teacher capacity and instructional practice in the integration of educational technology for emergent bilingual students. Computers \& Education, 126, 417-432.

Donkor, A. (2018). In-service teachers' use of ICT in teaching Mathematics in Ghana. A case study in the Cape Coast Metropolis. Tesis Dr. Fal, University of Cape Coast.

Educational Technology Division of Malaysia. (2017). Dokumentasi Kajian \& Laporan Pemantauan 2013-2015.

Ghavifekr, S., Kunjappan, T., Ramasamy, L. \& Anthony, A. (2016) .Teaching and learning with TMK tools: Issues and challenges from teachers' perceptions. Malaysian Online Journal of Educational Technology, 4(2), 38-57.

Hamzah, M. (2020, April 19). Sedia hadapi kelas maya sesuai normal baharu. Berita Harian. https://www.bharian.com.my/berita/nasional/2020/04/679003/sedia-hadapi-kelas-maya-sesuainormal-baharu

Kementerian Pendidikan Malaysia. (2018). Annual Report 2017: Malaysian Education Blueprint 2013-2025. Malaysia: Putrajaya.

Kumar, H. (2017). Two criteria for good measurements in research: Validity and reliability. Annals of Spiru Haret University Economic Series, 8 (17), 4.

Kurt, S. (2018). TPACK: Technological pedagogical content knowledge framework. https://educationaltechnology.net/technological-pedagogical-content-knowledge-tpackframework/

Luik, P., Taimalu, M. \& Suviste, R. (2018). Perceptions of technological, pedagogical and content knowledge (TPACK) among pre-service teachers in Estonia Education and Information Technologies, 23(2), 741-755.

Maican, C. I., Cazan, A.-M., Lixandroiu, R. C., \& Dovleac, L. (2019). A study on academic staff personality and technology acceptance: The case of communication and collaboration applications. Computers \& Education 128:113-131.

Mailizar, M \& Fan, L. (2020). Indonesian teachers' knowledge of ICT and the use of ICT in secondary mathematics teaching. EURASIA Journal of Mathematics, Science and Technology Education, $16(1)$.

Mailizar, M. (2018). Investigating Indonesian teachers' knowledge and use of ICT in mathematics teaching. Tesis Dr. Fal, University Of Southampton.

Mazana, M.Y., Montero, C.S. \& Oyelere, S.S. (2019). Information and communication technology in Mathematics education - Integration readiness in Tanzania Higher Education Institutions. ICT4D, 552, 409-420.

Mcculloch, A. W., Hollebrands, K., Lee, H., \& Harrison, T. (2018). Computers \& education factors that influence secondary mathematics teachers' integration of technology in Mathematics lessons. Computers \& Education, 123(4), 26-40. 
Mensah, J. 2018. Assessment of Mathematics tutors' TMK integration into teaching and learning of Mathematics in Colleges of Education of Ghana. International Journal of Scientific Research in Science and Technology, 4(9), 284-294.

Mishra, P., \& Koehler, M. J. (2006). Technological pedagogical content knowledge: A framework for teacher knowledge. Teachers College Record, 108 (6), 1017-1054.

National Council of Teachers of Mathematics. (2015). Strategic Use of Technology in Teacher and Learning Mathematics. Reston, VA: Author.

NCTM. (2000). Principles and Standards for School Mathematics (Vol. 1). National Council of Teachers of Mathematics.

Nordin, H, \& Ariffin. (2016). Validation of a technological pedagogical content knowledge instrument in a Malaysian secondary school context. Malaysian Journal of Learning and Instruction (MJLI), 13, 1-24.

Osman, H. (2020, April 19). Carian 'Google Classroom' tertinggi, bukti guru kita rajin. Berita Harian. https://www.bharian.com.my/berita/nasional/2020/04/678951/carian-google-classroom-tertinggibukti-guru-kita-rajin

Parrot, M.A.S. \& Leong, K.E. (2018). Impact of using graphing calculator in problem solving. International Electronic Journal Of Mathematics Education, 13(3), 139-148.

Pelan Pembangunan Pendidikan Malaysia. (2013). Pelan Pembangunan Pendidikan Malaysia 2013 2025. Education, 27(1), 1-268.

Qualtrics. (2020). Determining sample size: How to make sure u get the correct sample size? https://www.qualtrics.com/au/experience-management/research/determine-sample-size/

Ravendran, D.R. \& Daud, M.Y. (2019). Faktor - faktor yang mempengaruhi guru Matematik sekolah rendah dalam mengintegrasikan penggunaan teknologi dalam PdPc. Jurnal Dunia Pendidikan, 1 ( 3), 24-33.

Razak, N, Jalil, H. \& Ismail, I. (2019). Challenges in TMK integration among Malaysian public primary education teachers: The roles of leaders and stakeholders. International Journal of Emerging Technologies in Learning, 14(24), 184-205.

Seng, C.L., Sii, N.Y., Isawasan, P., Chen, K.L. \& Seng, P.L. (2016). Factors influencing teachers' intention to adopt TMK into teaching using partial least square technique methods. Proceedings of the 3rd International Conference on Applied Science and Technology (ICAST'18), 1-9.

Sheila, A. (2016). Integrating Information Communication and Technology in Mathematics education at secondary level, a case of Nairobi County, Kenya. Tesis Dr. Fal, Universiti Kenyatta.

Shulman, L.S. (1986). Those who understand: Knowledge growth in teaching. Educational Researcher, $15(2), 4-14$.

Stein, H., Gurevich, I., \& Gorev, D. (2020). Integration of technology by novice mathematics teachers-what facilitates such integration and what makes it difficult?. Education and Information Technologies, 25 (1), 141-161.

Suárez-Rodríguez, J., Almerich, G., Orellana, \& Díaz-García, I. (2018). A basic model of integration of ICT by teachers: Competence and use. Educational Technology Research and Development, 66(5), 1165-1187.

Vongkulluksn, V. W., Xie, K., \& Bowman, M. A. (2018). The role of value on teachers' internalization of external barriers and externalization of personal beliefs for classroom technology integration, Computers \& Education, 118, 70-81.

Zaira, R., Bahador Zolkefli, B. \& Saidon, K. (2016). Faktor-faktor yang mempengaruhi penggunaan Vle Frog dalam kalangan guru di sekolah menengah. Proceeding of ICECRS, 1023-1032.

Zengin, Y., \& Tatar, E. (2017). Integrating dynamic mathematics software into cooperative learning environments in mathematics. Journal of Educational Technology \& Society, 20(2), 74-88.

Zolkefli, B., Osman, S.. \& Saidon, K. (2017). Faktor-faktor yang mempengaruhi pengintegrasian teknologi pengajaran berdasarkan Model TPACK dalam kalangan guru Matematik. Proceedings of the ICECRS, 66-73. 